\title{
Ktech corp.
}

901 PENnsylvania AVENUE, N.E. / ALBUQUeROUE, NEW MEXICO 87110 / (505) 268-3379

KTECH TR-80-01

| VOL. II

SHOCK CHARACTERIZATTON OF EXPLOSIVE MATERIALS

VOL. II: 5-CYANOTETRAZOLATOPENTAAMINE-COBALT (III) PERCHLORATE (CP)

\section{RTECH-TR--80-01-VOI.2 \\ DE84 012282}

L. M. Lee

B. D. Jenrette

MAY 1980

Final Report on Subtask 02-04/00

Supported by the AFWL under

Contract F29601-79-C-0017 


\section{DISCLAIMER}

Portions of this document may be illegible in electronic image products. Images are produced from the best available original document. 


\section{ABSTRACT}

The results of an experimental program to generate dynamic mechanical properties data for an unreacted porous explosive material are discussed and the data presented. Stress-particle velocicy Hugoniot data were experimentally determined for 5-Cyanotetrazolatopentaamine-Cobalt(III) Perchlorate (CP) using flat plate impact techniques. The CP samples were fabricated to the desired bulk sample density and size using a pressing technique. Samples with nominal densities of 1.47 and $1.66 \mathrm{~g} / \mathrm{cm}^{3}$ were investigated. The Hugoniot data for both sample densities showed essentially the same compaction behavior at stress levels above $5 \mathrm{kbar}$. The stress-time data showed major stress increases following impact, indicating initiation of a lower order chemical reaction. A constant high amplitude stress plateau was achieved after impact in a number of the experiments. These data provide both shock initiation and reaction rate information for $\mathrm{CP}$.

\section{DISCLAIMER}

This report was prepared as an account of work sponsored by an agency of the United States Government. Neither the United States Government nor any agency thereof, nor any of their employees, makes any warranty, express or implied, or assumes any legal liability or responsibility for the acsuracy, completeness, or usefulness of any information, apparatus, product, or process disclosed, or represents that its use would not infringe privately owned rights. Reference herein to any specific commercial product, process, or service by trade name, trademark, manufacturer, or otherwise does not necessarily constitute or imply its endorsement, recommendation, or favoring by the United States Government or any agency thereof. The views and opinions of authors expressed herein do not necessarily state or reflect those of the United States Government or any agency thereof 


\section{PREFACE}

The experimental work described in this report was conducted under Contract F29601-79-C-0017 for the Air Force Weapons Laboratory (AFWL). The technical program was performed for Sandia Laboratories, Albuquerque, NM. The AFWL Project Officer was Mr. Kenneth D. Smith and the Sandia Laboratories Technical Consultant was Dr. Philip L. Stanton. The authors are indebted to Dr. Stanton for his helpful suggestions regarding explosive material physical characteristics and safe handling procedures. The experimental work was performed at the AFWL Impact Facility by Ktech Corporation personnel. Mr. L. M. Lee was the Principal Investigator and was assisted by Messrs. B. D. Jenrette and C. G. Newcomb. 


\section{CONTENTS}

\section{$\underline{\text { Section }}$}

Page

I INTRODUCTION

II MATERIAL DESCRIPTION

III EXPERTMENTAL PROCEDURES AND ANALYSIS 9

1. Hugoniot Experiments 9

2. Data Analysis 11

IV EXPERTMENTAL RESULTS AND DISCUSSION

V CONCLUSIONS AND RECOMMENDATIONS 31

$\begin{array}{ll}\text { REFERENCES } & 32\end{array}$ 


\section{ILLUSTRATIONS}

Figure

$\underline{\text { Page }}$

1 Schematic of explosive sample and plexiglass backer used to

8 hold the sample

2 Schematic of the projectile and target configuration used to 10 generate the explosive Hugoniot data

3 Representative quartz gauge records from explosive Hugoniot shots and schematic diagram data analysis technique

4 Data trace from check shot 1230 with steel impacting a plexiglass sample

5 Stress-time data for Shot 1259, using a WC target and impactor to evaluate the transmitted wave shape for a step input of approximately $100 \mathrm{kbars}$

6 Stress-particle velocity Hugoniot data for porous CP explosive

7 Shock velocity-particle velocity Hugoniot data for porous $\mathrm{CP}$ explosive

8 Stress-specific volume Hugoniot data for porous CP explosive

9 Sumary of low density CP impact test data

10 Summary of high density CP impact test data

11 Sumary of high density CP impact test data

12 Summary of low density CP stress-time data from impact experiments

13 Summary of high density CP stress-time data from impact experiments

\section{TABLES}

Table .

$\underline{\text { Page }}$

1 Summary of Hugoniot data for low density explosive (CP)

2 Summary of Hugoniot data for high density explosive (CP)

3 Summary of peak stresses recorded in $\mathrm{CP}$ impact tests 


\section{SECTION I}

\section{INTRODUCTION}

Explosive materials are utilized in a number of system and component applications. Effective design and performance analyses of systems employing explosive materials are dependent upon proper modeling of the materials' thermodynamic behavior. A complete thermodynamic equation of state is based on numerous types of material properties data, including the shock response or Hugoniot of the unreacted explosive. The primary purpose of the study reported here was to experimentally determine the shock loading behavior of unreacted explosive materials and provide information to support reaction rate modeling.

The porous explosive studied was 5-Cyanotetrazolatopentaamine-Cobalt(III) Perchlorate (CP). Pressed CP samples were supplied to the AFWL Material Response Impact Facility in cylindrical shape. Two sets of samples were made, with one set having a nominal bulk density of $1.47 \mathrm{~g} / \mathrm{cm}^{3}$ and the other set $1.66 \mathrm{~g} / \mathrm{cm}^{3}$. Theoretical solid density of the CP mixture was determined to be $1.97 \mathrm{~g} / \mathrm{cm}^{3}$. Binder was used in fabricating the samples; however, the low density samples had minimal structural integrity.

The impact experiments, conducted using the gas gun facilities at the AFWL Material Response Impact Facility, provided Hugoniot data for both densities of $\mathrm{CP}$. The low density explosive samples had limited structural integrity and were not flat, which hampered the experimental setup. The Hugoniot data, generated using a projectile-mounted piezoelectric transducer technique, were used to define the shock compaction characteristics of the porous explosive up to $60 \mathrm{kbar}$. The Hugoniot data for both sample densities indicated essentially full compaction was achieved at about $5 \mathrm{kbar}$. The stress-particle velocity data were transformed 
to the stress-specific volume and shock velocity-particle velocity planes using the Hugoniot equations to facilitate utilization of the experimental results.

The experimental technique used to generate the Hugoniot data was designed to measure essentially an instantaneous change in stress, which remained at a constant amplitude during the recording time of the transducer $(1.0 \mu \mathrm{s})$. Behavior of this type is typical for unreactive porous and solid materials. Experimental data generated in this program showed substantial stress increases as a function of time following the initial stress jump produced by the impact. Both densities of explosive displayed the same type of behavior. The stress increase was attributed to initiation of a lower order (deflagration) chemical reaction. Initiation was observed in the lower density material when impact stress exceeded $8 \mathrm{kbar}$, with $12 \mathrm{kbar}$ being required to produce the same type of behavior in the higher density samples. The increasing stress reached a plateau during the recording time of the experiment when impact stresses were greater than 15 and $20 \mathrm{kbar}$ in the 1.47 and $1.66 \mathrm{~g} / \mathrm{cm}^{3}$ samples, respectively. The high amplitude stress (70 to $100 \mathrm{kbar}$ ) plateau was achieved approximately $0.3 \mathrm{\mu s}$ after impact and remained essentially constant during the one-dimensional read time of the experiment. The experimental results provide a unique set of data to support reaction rate modeling of the $\mathrm{CP}$, in addition to providing unreacted Hugoniot data. 


\section{SECTION II}

\section{MATERIAL DESCRIPTION}

The explosive samples used in the test program were pressed for Sandia Laboratories by Unidynamics* using material from production lot number EL-47344. The CP (5-Cyanotetrazolatopentaamine-Cobalt(III) Perchlorate) was formulated to the specifications in Reference 1. A solid particle density of $1.965 \mathrm{~g} / \mathrm{cm}^{3}$ has been determined using a picknometer technique, while $1.99 \mathrm{~g} / \mathrm{cm}^{3}$ has been reported for single crystal CP (Ref. 2).

The low density CP samples were fabricated using a one percent Viton A binder and a consolidation pressure of approximately $0.7 \mathrm{kbar}$. The average density of the ten samples fabricated for the impact test program was $1.47 \pm$ $0.01 \mathrm{~g} / \mathrm{cm}^{3}$. The impact surface of the low density samples was not flat, which is a requirement for conducting Hugoniot tests. The samples typically were high in the central region of the disk by as much as $0.1 \mathrm{~mm}$. Curvature of the sample impact surface negated accurate target and projectile alignment and produced long rise times of the initial stress pulse $(0.05 \mu \mathrm{s})$. The higher density CP pellets were fabricated from the same material lot and were also provided as free-standing disks. The higher density samples were nominally $1.66 \pm 0.01 \mathrm{~g} / \mathrm{cm}^{3}$. A one percent Viton A binder was used in conjunction with a consolidation pressure of $2.58 \mathrm{kbar}$. The higher density CP samples were not flat either; however, they were substantially better than the $1.47 \mathrm{~g} / \mathrm{cm}^{3}$ samples.

* Unidynamics/Phoenix, Inc., Box 2990, Phoenix, Arizona 85062.

+ Marchi, D. L., Sandia Laboratories, Private Communication.

1. Fleming, W. and Fronabarger, J. W. (Unidynamics) and Searcy, J. Q. (Sandia Laboratories), "Preparation of 5-Cyanotetrazolatopentaamine-Cobalt (III) Perchlorate, (CP): A New Material for Detonator Applications," Proceeding of ADPA Meeting, Albuquerque, NM, May 15-17, 1979.

2. Graber, E. J. and Morrison B., "The Secondary Explosive 5-Cyanotetrazolatopentaamine-Cobalt(III) Perchlorate," Proceedings, American Crystallography Association, University of Oklahoma, Norman, OK, March 19-24, 1978. 
A backer plate of plexiglass was attached to the free-standing samples to facilitate target fabrication and minimize sample breakage. The backer plate and explosive sample were bonded together using 5-minute cure epoxy ${ }^{*}$ applied to the circumference of the recess in the backer plate (Figure 1). A minimum amount of epoxy was used on the circumference and a thin film was applied to the flat surface in contact with the sample. The small amount and location of epoxy used in mounting the sample did not influence the Hugoniot measurements.

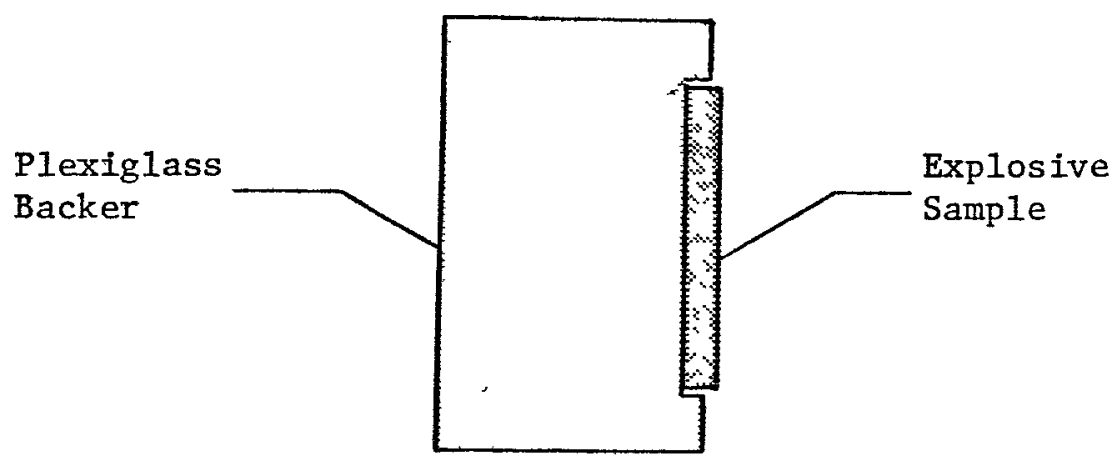

Figure 1. Schematic of explosive sample and plexiglass backer used to hold the sample.

* Devcon "5 Minute" epoxy, Stock No. 14250, Devcon Corp., Danvers, MA 01923. 
SECTION III

EXPERTMENTAL PROCEDURES AND ANALYSIS

The dynamic response of the porous, unreacted CP was determined under conditions of uniaxial-strain shock loading. The shock loading characteristics of the explosive material were obtained from plate-impact experiments performed with a 102-mm bore compressed gas gun (Ref. 3). Analysis of the shock loading data employed the Rankine-Hugoniot jump equations, which assume steady wave behavior and thermodynamic equilibrium behind the shock front (Ref. 4).

\section{HUGONIOT EXPERIMENTS}

The basic experimental configuration used to generate the Hugoniot data is shown schematically in Figure 2. In this configuration the piezoelectric transducer used to measure stress was mounted in the projectile rather than the target. The projectile-mounted transducer design was adopted so that the explosive sample could be placed in the target and not subjected to any acceleration loads. Previous experience indicated that pressed pyrotechnic and explosive samples cannot be mounted on projectiles and directly impacted into targets successfully because of their limited structural integrity (Ref. 5).

The explosive sample was impacted with either a $4340 R_{c} 52$ steel or a tungsten carbide (WC) ${ }^{*}$ plate backed with a shunted quartz gauge (Ref. 6) to make

* Type K-68, Kennametal Inc., Latrobe, PA.

3. Lee, L. M., Operation of the Air Force Weapons Laboratory Material Response Impact Facility, AFWL-TR-75-287, Air Force Weapons Laboratory, Kirtland AFB, NM, March 1976.

4. Rice, M. H., McQueen, R. G. and Walsh, J. M., in Solid State Physics, "Compression of Solids by Strong Shock Waves," F. Seitz and D. Turnbull, Eds., Academic Press, New York, 1958, Vo1. 6, pp. 1-63.

5. Lee, L. M., Shock Compaction Behavior of Porous Titanium Hydride-Potassium Perchlorate, Ktech TR-76-06, Albuquerque, NM, July 1976.

6. Graham, R. A., Neilson, F. W. and Benedick, W. B., "Piezoelectric Current from Shock-Loaded Quartz--A Submicrosecond Stress Gauge," J. Appl. Phys., 36, No. 4, 1965, pp. 1775-1783. 


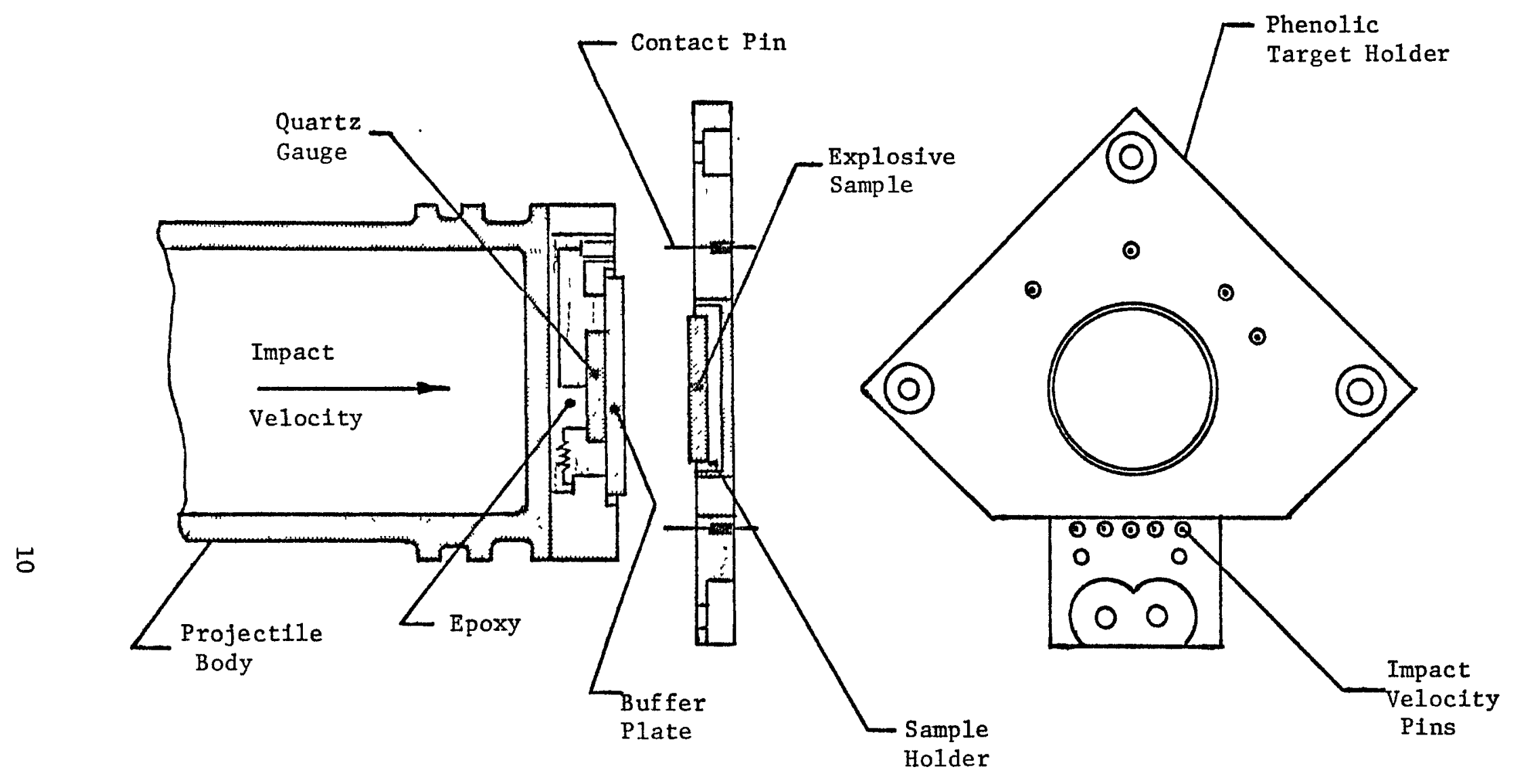

Figure 2. Schematic of the projectile and target configuration used to generate the explosive Hugoniot data. 
the stress measurement. Impact stress data below $20 \mathrm{kbar}$ were obtained using a steel buffer plate, and above $20 \mathrm{~kb}$ ar using WC. The buffer plate separated the quartz gauge from the porous explosive sample, which minimized gauge failure caused by local discontinuities at the gauge front electrode. The thicknesses of the sample, buffer plate, and quartz gauge were designed such that the initial stress wave generated at impact could propagate into the quartz gauge without being influenced by side or edge rarefaction waves. The measured experimental quantities included impact velocity and the time resolved current output of the quartz gauge as measured by the voltage across a 50-ohm termination resistor. Impact velocity was determined from time interval readings with t0.1 ns resolution, obtained from three counters triggered by charged pins with known distance intervals. Impact velocity was calculated from these data with an estimated maximum error of \pm 0.4 percent. The maximum experimental error associated with the quartz gauge measurements was estimated to be \pm 3 percent.

\section{DATA ANALYSIS}

The buffer plate experiments yielded stress-particle velocity data directly, as shown schematically in Figure 3. Continuity of stress and particle velocity across the buffer plate-explosive sample interface requires:

$$
\Delta \sigma_{s}=\Delta \sigma_{b}
$$

and

$$
\Delta u_{s}=I V-\Delta u_{b}
$$

where $\Delta \sigma_{s}$ and $\Delta \sigma_{b}$ are the stress changes in sample and buffer plate, respectively, and $\Delta \mathrm{u}_{\mathrm{s}}$ and $\Delta \mathrm{u}_{\mathrm{b}}$ are the particle velocity changes in the sample and buffer plate, respectively. Impact velocity is denoted IV. The stress and particle velocity state reached in the buffer after impact was calculated from the measured quartz 
Shot 1253

Impact Velocity $=0.272 \mathrm{~mm} / \mu \mathrm{s}$

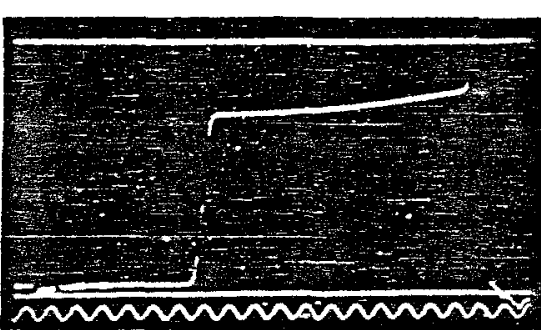

$0.1 \mu \mathrm{s} / \mathrm{Time}$ Mark

1.5008 Volts Cal.
Shot 1251

Impact Velocity $=0.515 \mathrm{~mm} / \mathrm{us}_{\mathrm{s}}$

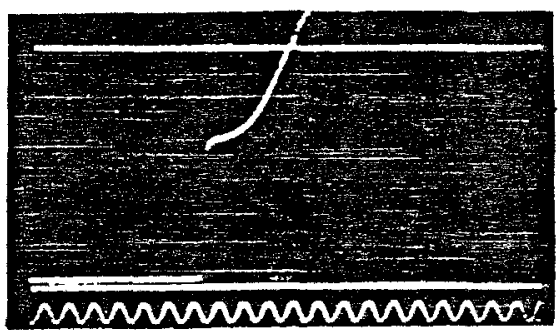

0.1 us/Time Mark

5.004 Volts Cal.

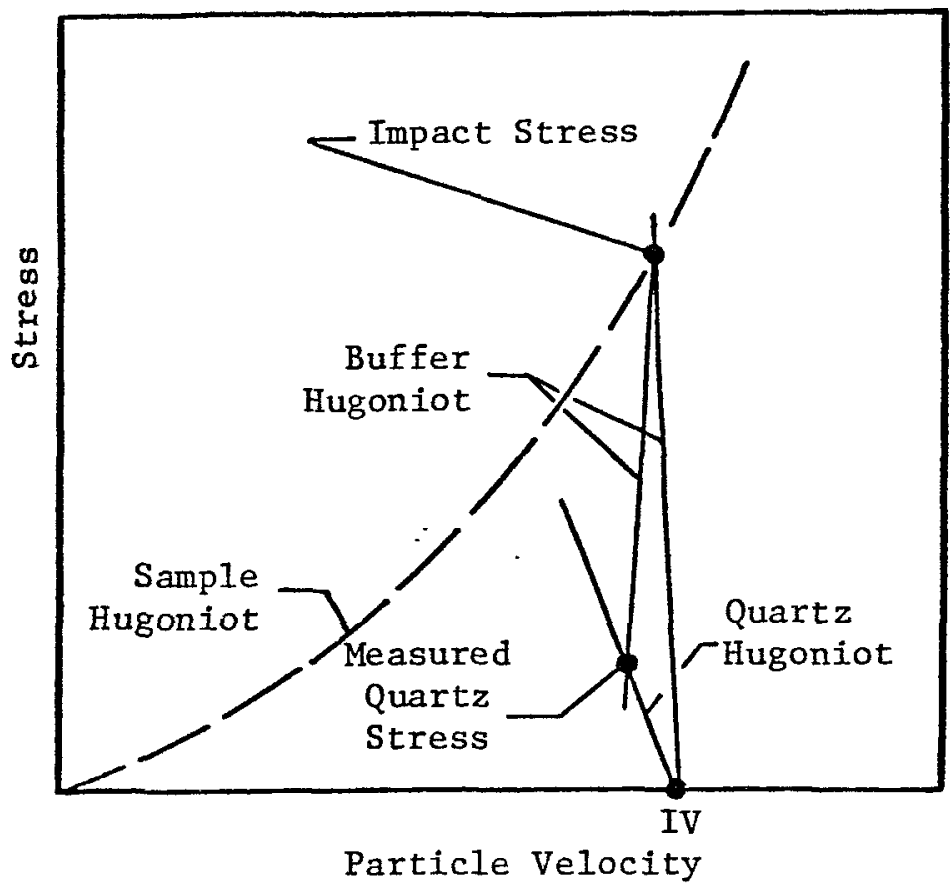

Figure 3. Representative quartz gauge records from explosive Hugoniot shots and schematic diagram data analysis technique. 
gauge stress amplitude, $\sigma_{q}$, and the known Hugoniots for the steel (Ref. 7) and WC* buffer material and quartz crystal. These experiments do not provide explicit information on stress wave shape or the loading path followed by the porous explosive. Measurements of the wave profile after it has propagated through the unreacted material are necessary to suitably define this portion of material response. The stress-particle velocity data from the buffer plate experiments were transformed to the shock velocity-particle velocity and stress-specific volume plane using the Hugoniot equations and assuming a zero Hugoniot elastic 1imit.

The initial stress jump recorded by the quartz crystal was used to determine the Hugoniot point. The initial stress jump due to impact was clearly defined for Shot 1253 in Figure 3; however, the point was not so easily defined for Shot 1251 because of the increase in stress due to chemical reaction. The approach taken in the data analyses was to use the point defined by the intersection of a line drawn through the initial rise with a line drawn through the second major slope. The analysis technique allowed all of the experimental data to be evaluated; however, when the stress increased at a rapid rate immediately following impact, definition of a discrete Hugoniot point was somewhat subjective.

* Karnes, C. H., Sandia Laboratories, Private Communication.

7. Butcher, B. M. and Canon, J. R., "Influence of Work-Hardening on the Dynamic Stress-Strain Curves of 4340 Stee1," AIAA Journal, 2, No. 12, p. 2174. 


\section{SECTION IV \\ EXPERTMENTAL RESULTS AND DISCUSSION}

The experimental program provided information defining the shock compaction behavior of porous $\mathrm{CP}$ up to $60 \mathrm{kbar}$, as well as reaction rate information. The impact testing portion of the program was broken into three phases: (1) system check shots; (2) low density explosive Hugoniot shots; and (3) high density explosive shots. The system check shots were fired to verify the experimental design and to check all recording systems. Two check shots were conducted using a plexiglass sample instead of CP. The well documented plexiglass Hugoniot (Refs. 8 and 9) was used in conjunction with the steel Hugoniot to calculate the impact stress amplitude using the measured impact velocity. The calculations were then compared with the quartz gauge results. Differences of 1.1 and 2.0 percent. existed between the calculations and data. The degree of nonplanarity at impact was also obtained from these two check shots, with tilt angles of between 1.0 and $1.7 \times 10^{-3}$ radians being measured. A data trace from one of the check shots is shown in Figure 4.

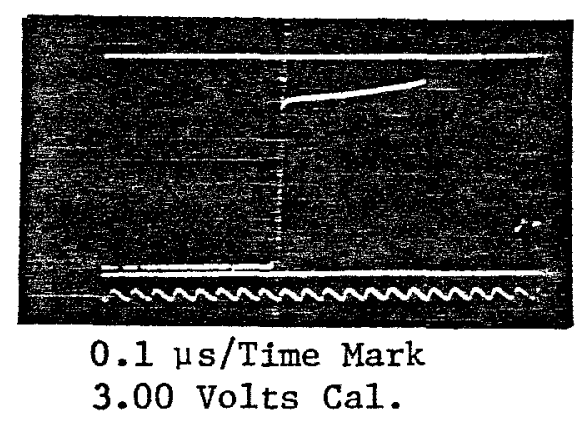

Figure 4. Data trace from check shot 1230 with steel impacting a plexiglass sample.

8. Barker, L. M. and Hollenbach, R. E., "Shock-Wave Studies of PMMA, Fused Silica, and Sapphire," J. App1. Phys., 41, No. 10, Sept. 1970, p. 4208.

9. Schuler, K. W. and Nunziato, J. W., "The Dynamic Mechanical Behavior of Polymethyl Methacrylate," Rheologica Acta, Vol. 13, 1974, pp. 265-273. 
The stress plateau resulting from chemical reaction was substantially higher in amplitude than any stress level considered during the experiment design. The impact experiments were designed to exercise the buffer plates and quartz gauges in the elastic range. However, the 100-kbar plateau was beyond the elastic range of the tungsten carbide buffer plates used in the experiment. The particular carbide (K-68) responds in a linear elastic fashion to $35 \mathrm{kbar}$ before nonlinear effects are measurable. The propagation speed of a stress increment at $100 \mathrm{kbar}$ in WC is 12 percent less than the elastic propagation speed associated with stresses from 0 to $35 \mathrm{kbar}$. The net effect of operating the carbide at stresses beyond the elaștic limit was an additional spreading of the input wave above $35 \mathrm{kbar}$ as it propagates through the carbide. The buffer plate thickness used in the test program was $3.18 \mathrm{~mm}$. If a $100-\mathrm{kbar}$ stress wave was instantaneously applied to the front surface of the WC buffer, the nonlinear material response would cause a $0.06-\mu$ s spreading of the wave when it arrived at the rear surface of the buffer.

An experiment using a WC target and impactor was conducted to evaluate the transmitted wave shape for a step input of $100 \mathrm{kbar}$. The results of the test are shown in Figure 5. A slight deviation in the rise of the stress pulse is evident and correlates to the nonlinear behavior of the carbide. The time correction produced by the nonlinear material behavior was not applied to the experimenta 1 results obtained on $C P$ because it was small $(0.03$ to $0.06 \mu s)$ and could not be clearly separated from the effects of nonplanar impact. The results of Shot 1259 clearly show that the nonlinear behavior of WC at 100 kbar did not compromise the validity of the recorded CP stress-time data. 


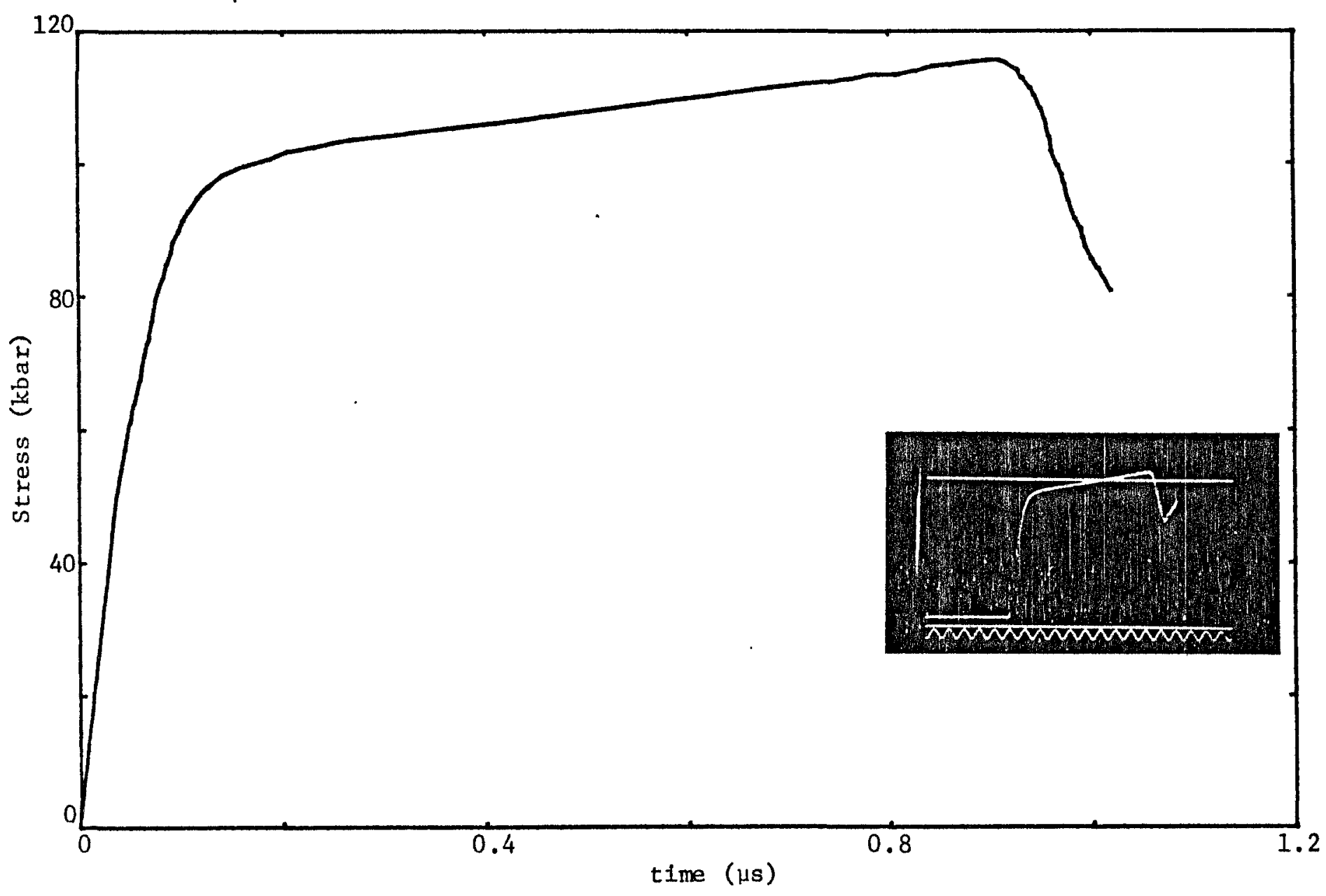

Figure 5. Stress-time data for Shot 1259, using a WC target and Impactor to evaluate the transmitted wave shape for a step input of approximately $100 \mathrm{kbars}$. 
The results of the impact experiments on the 1.47 and $1.66 \mathrm{~g} / \mathrm{cm}^{3} \mathrm{CP}$ samples are given in Tables 1 and 2, respectively. The sample number and type of experiment used to generate the data are also 1isted. Some of the results listed as Hugoniot data are questionable, as indicated in the tables. Definition of the unreacted CP Hugoniot state was questionable when chemical reaction produced a rapid stress increase immediately after impact. The stress amplitude determined in these experiments, using the data analysis technique described in Section III, was larger than the Hugoniot state for the unreacted material because it was a combination of impact induced stress and pressure due to chemical energy release. Utilization of an artificially high stress amplitude in the Hugoniot relations produced unrealistically large values of shock. velocity and specific volume. All of the experimental results for both densities of $\mathrm{CP}$ are included in Tables 1 and 2 and plotted in Figure 6. Also shown in Figure 6 are polynomial fits to the Hugoniot data determined using a least squares technique and constraining the fit through the origin. The data influenced by the chemical reaction were not included in the $\mathrm{fit}$, but are shown in Figure 6. The stress-particle velocity relation for the unreacted $1.47 \mathrm{~g} / \mathrm{cm}^{3} \mathrm{CP}$ is:

$$
\sigma=6.90 u+34.34 u^{2}
$$

and for the $1.66 \mathrm{~g} / \mathrm{cm}^{3}$ density material:

$$
\sigma=10.55 \mathrm{u}+56.28 \mathrm{u}^{2}
$$

where stress $\sigma$ is $\mathrm{kbar}$, and particle velocity $\mathrm{u}$ is $\mathrm{mm} / \mathrm{\mu s}$.

The stress-particle velocity data for the unreacted material were transformed to the shock velocity-particle velocity plane by using the Hugoniot jump equation. Shock velocity was calculated from:

$$
u_{1}=\frac{\Delta \sigma_{1}}{\Delta u_{1} \rho_{0}}
$$


TABLE 1

SUMMARY OF HUGONIOT DATA FOR LOW DENSITY EXPLOSIVE (CP)

\begin{tabular}{|c|c|c|c|c|c|c|c|c|c|}
\hline \multirow[b]{2}{*}{$\begin{array}{l}\text { Shot } \\
\text { No. }\end{array}$} & \multirow[b]{2}{*}{$\begin{array}{l}\text { Type of } \\
\text { Experiment }\end{array}$} & \multirow[b]{2}{*}{$\begin{array}{l}\text { Sample } \\
\text { Number }\end{array}$} & \multicolumn{3}{|c|}{ Initial Conditions } & \multicolumn{4}{|c|}{ Hugoniot Data } \\
\hline & & & $\begin{array}{l}\text { Impact } \\
\text { Velocity } \\
(\mathrm{mm} / \mathrm{ss})\end{array}$ & $\begin{array}{c}\text { Sample } \\
\text { Thick. } \\
\text { (mm) }\end{array}$ & $\begin{array}{l}\text { Sample } \\
\text { Density } \\
\left(\mathrm{g} / \mathrm{cm}^{3}\right)\end{array}$ & $\begin{array}{l}\text { Stress } \\
\text { (kbar) }\end{array}$ & $\begin{array}{l}\text { Particle } \\
\text { Velocity } \\
\text { (mm/ } \mathrm{s} \text { ) }\end{array}$ & $\begin{array}{l}\text { Shock } \\
\text { Velocity } \\
(\mathrm{mm} / \mu \mathrm{s})\end{array}$ & $\begin{array}{l}\text { Specific } \\
\text { Volume } \\
\left(\mathrm{cm}^{3} / \mathrm{g}\right) \\
\end{array}$ \\
\hline 1243 & $\mathrm{XQ} / 4340 \rightarrow \mathrm{CP}$ & 1 & 0.511 & 0.302 & 1.47 & 11.6 & 0.485 & 1.63 & 0.477 \\
\hline 1244 & $\mathrm{XQ} / 4340+\mathrm{CP}$ & 2 & 0.427 & 0.300 & 1.48 & 8.2 & 0.409 & 1.35 & 0.471 \\
\hline 1245 & $X Q / 4340+C P$ & 3 & 0.268 & 0.305 & 1.45 & $-m n$ & data due & gauge $\mathrm{fa}$ & re -r-- \\
\hline 1246 & $X Q / 4340 \rightarrow C P$ & 4 & 0.269 & 0.302 & 1.47 & 4.2 & 0.260 & 1.10 & 0.519 \\
\hline $1247^{*}$ & $\mathrm{XQ} / \mathrm{WC} \rightarrow \mathrm{CP}$ & 5 & 0.693 & 0.302 & 1.46 & 25.9 & 0.668 & 2.66 & 0.513 \\
\hline $1248 *$ & $\mathrm{XQ} / \mathrm{WC} \rightarrow \mathrm{CP}$ & 6 & 0.616 & 0.297 & 1.49 & 21.0 & 0.595 & 2.37 & 0.502 \\
\hline $1249 *$ & $\mathrm{XQ} / \mathrm{WC} \rightarrow \mathrm{CP}$ & 7 & 0.617 & 0.302 & 1.46 & 18.3 & 0.599 & 2.09 & 0.489 \\
\hline $1250 *$ & $\mathrm{XQ} / \mathrm{WC} \rightarrow \mathrm{CP}$ & 8 & 0.695 & 0.302 & 1.46 & 19.0 & 0.676 & 1.93 & 0.444 \\
\hline
\end{tabular}

* Data point influenced by explosive reaction. 
TABLE 2

SUMMARY OF HUGONIOT DATA FOR HIGH DENSITY EXPLOSIVE (CP)

\begin{tabular}{|c|c|c|c|c|c|c|c|c|c|}
\hline \multirow[b]{2}{*}{$\begin{array}{l}\text { Shot } \\
\text { No. }\end{array}$} & \multirow[b]{2}{*}{$\begin{array}{l}\text { Type of } \\
\text { Experiment }\end{array}$} & \multirow[b]{2}{*}{$\begin{array}{l}\text { Sample } \\
\text { Number }\end{array}$} & \multicolumn{3}{|c|}{ Initial Conditions } & \multicolumn{4}{|c|}{ Hugoniot Data } \\
\hline & & & $\begin{array}{l}\text { Impact } \\
\text { Velocity } \\
(\mathrm{mm} / \mu \mathrm{s}) \\
\end{array}$ & $\begin{array}{l}\text { Sample } \\
\text { Thick. } \\
\text { (mm) }\end{array}$ & $\begin{array}{l}\text { Sample } \\
\text { Density } \\
\left(\mathrm{g} / \mathrm{cm}^{3}\right) \\
\end{array}$ & $\begin{array}{l}\text { Stress } \\
\text { (kbar) }\end{array}$ & $\begin{array}{l}\text { Particle } \\
\text { Velocity } \\
(\mathrm{mm} / \mu \mathrm{s}) \\
\end{array}$ & $\begin{array}{c}\text { Shock } \\
\text { Velocity } \\
\text { (mm/ } / \mathrm{ss} \text { ) } \\
\end{array}$ & $\begin{array}{l}\text { Spectfic } \\
\text { Volume } \\
\left(\mathrm{cm}^{3} / \mathrm{g}\right) \\
\end{array}$ \\
\hline 1251 & $\mathrm{XQ} / 4340 \rightarrow \mathrm{CP}$ & 11 & 0.515 & 0.297 & 1.66 & 17.3 & 0.477 & 2.19 & 0.471 \\
\hline 1252 & $X Q / 4340 \rightarrow C P$ & 12 & 0.417 & 0.297 & 1.65 & 12.4 & 0.389 & 1.93 & 0.483 \\
\hline 1253 & $X Q / 4340+C P$ & 13 & 0.272 & 0.297 & 1.65 & 6.2 & 0.258 & 1.44 & 0.498 \\
\hline 1254 & $\mathrm{XQ} / \mathrm{WC}+\mathrm{CP}$ & 14 & 0.619 & 0.297 & 1.66 & 27.9 & 0.591 & 2.84 & 0.477 \\
\hline 1255 & $\mathrm{XQ} / \mathrm{WC} \rightarrow \mathrm{CP}$ & 15 & 0.698 & 0.297 & 1.66 & 30.9 & 0.668 & 2.79 & 0.458 \\
\hline 1256 & $\mathrm{XQ} / \mathrm{WC} \rightarrow \mathrm{CP}$ & 16 & - & 0.297 & 1.65 & Sample cr & ed during & target al1g & ent--no d \\
\hline $1257 *$ & $\mathrm{XQ} / \mathrm{WC} \rightarrow \mathrm{CP}$ & 17: & 0.800 & 0.297 & 1.66 & 51.0 & 0.740 & 4.15 & 0.495 \\
\hline $1258 *$ & $\mathrm{XQ} / \mathrm{WC}+\mathrm{CP}$ & 18 & 0.796 & 0.297 & 1.66 & 62.1 & 0.734 & 5.10 & 0.516 \\
\hline
\end{tabular}

* Data point influenced by explosive reaction. 


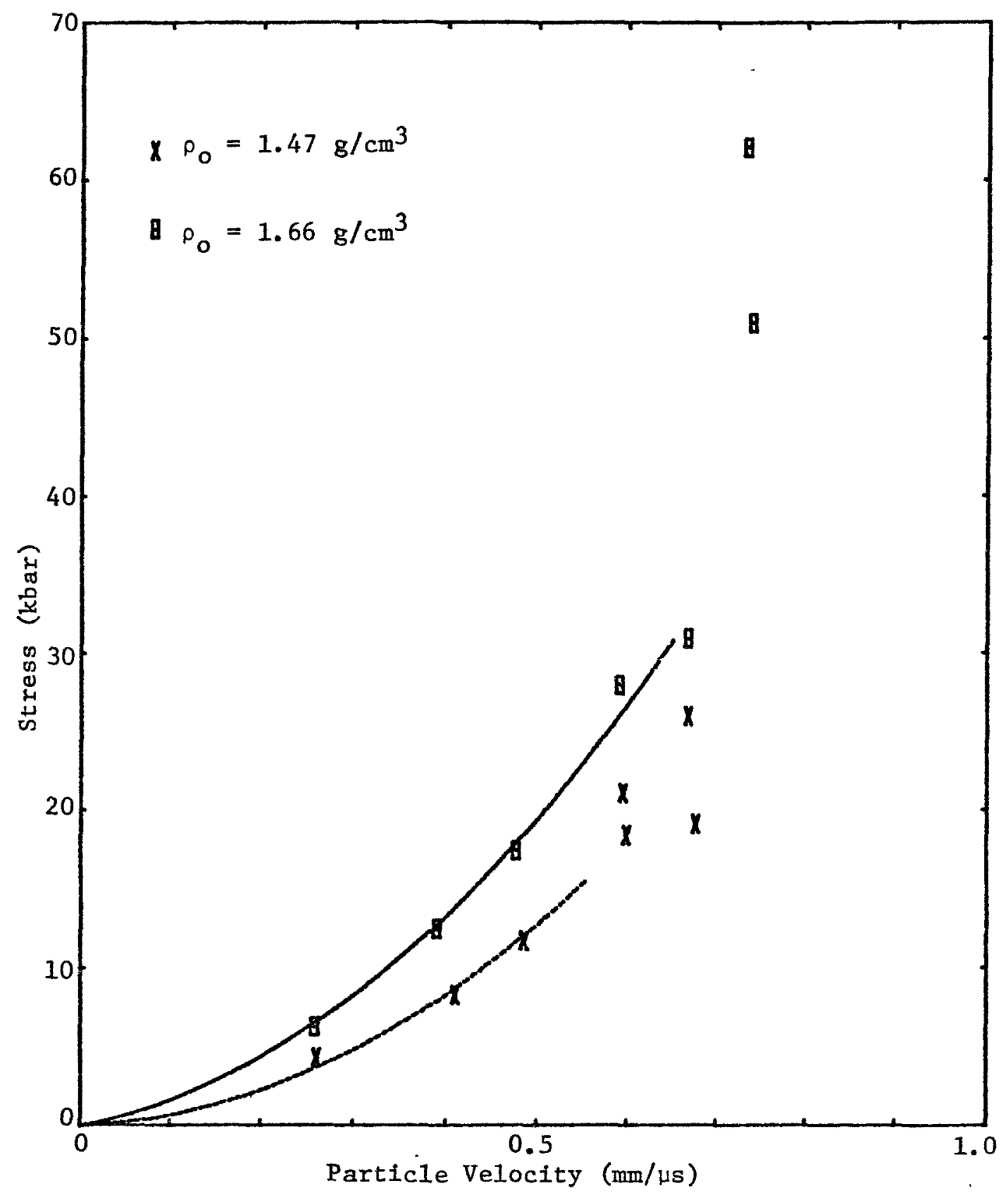

Figure 6. Stress-particle velocity Hugoniot data for porous CP explosive. 
where $U_{1}$ is shock velocity, $\Delta \sigma_{1}$ is the change in stress, $\Delta u_{1}$ is the change in particle velocity, and $\rho_{0}$ is the initial sample density. Linear fits to the two sets of data were obtained, as shown in Figure 7, with the relations being:

$$
\mathrm{U}=0.49+2.26 \mathrm{u}
$$

for the $1.47 \mathrm{~g} / \mathrm{cm}^{3}$ density material, and

$$
\mathrm{U}=0.54+3.57 \mathrm{u}
$$

for the $1.66 \mathrm{~g} / \mathrm{cm}^{3}$ density material, where $U$ and $u$ are $\mathrm{mm} / \mu \mathrm{s}$. The data were also transformed to the stress-specific volume plane using the Hugoniot equation:

$$
\rho_{1}=\frac{\rho_{0}}{1-\frac{\Delta \mathrm{u}_{1}}{U_{1}}}
$$

where $\rho_{1}$ is the material density at shock state 1 . Both densities of explosive material displayed essentially the same compaction response above $5 \mathrm{kbar}$ as shown in Figure 8.

The data traces recorded on both densities of CP are summarized in Figures . 9, 10 and 11 to show the rapid rise in stress following the initial impact. The slope of the stress-time data after the initial step is clearly increasing with increasing impact stress. The dynamic behavior of the high density $\mathrm{CP}$ was similar to the low density material. The slope of the stress-time data following the initial stress jump was lower for the $1.66 \mathrm{~g} / \mathrm{cm}^{3}$ than for the $1.47 \mathrm{~g} / \mathrm{cm}^{3}$ for a given impact stress. The data indicated the more porous, lower density samples were more sensitive to impact initiation than the higher density material.

A high amplitude stress plateau was recorded approximately 0.2 us after impact, which was attributed to the chemical reaction taking place in the explosive sample. A nominally 70-kbar plateau was observed in two experiments conducted on the low density $\mathrm{CP}$ when the impact stress was above $18 \mathrm{~kb}$ ar. A 


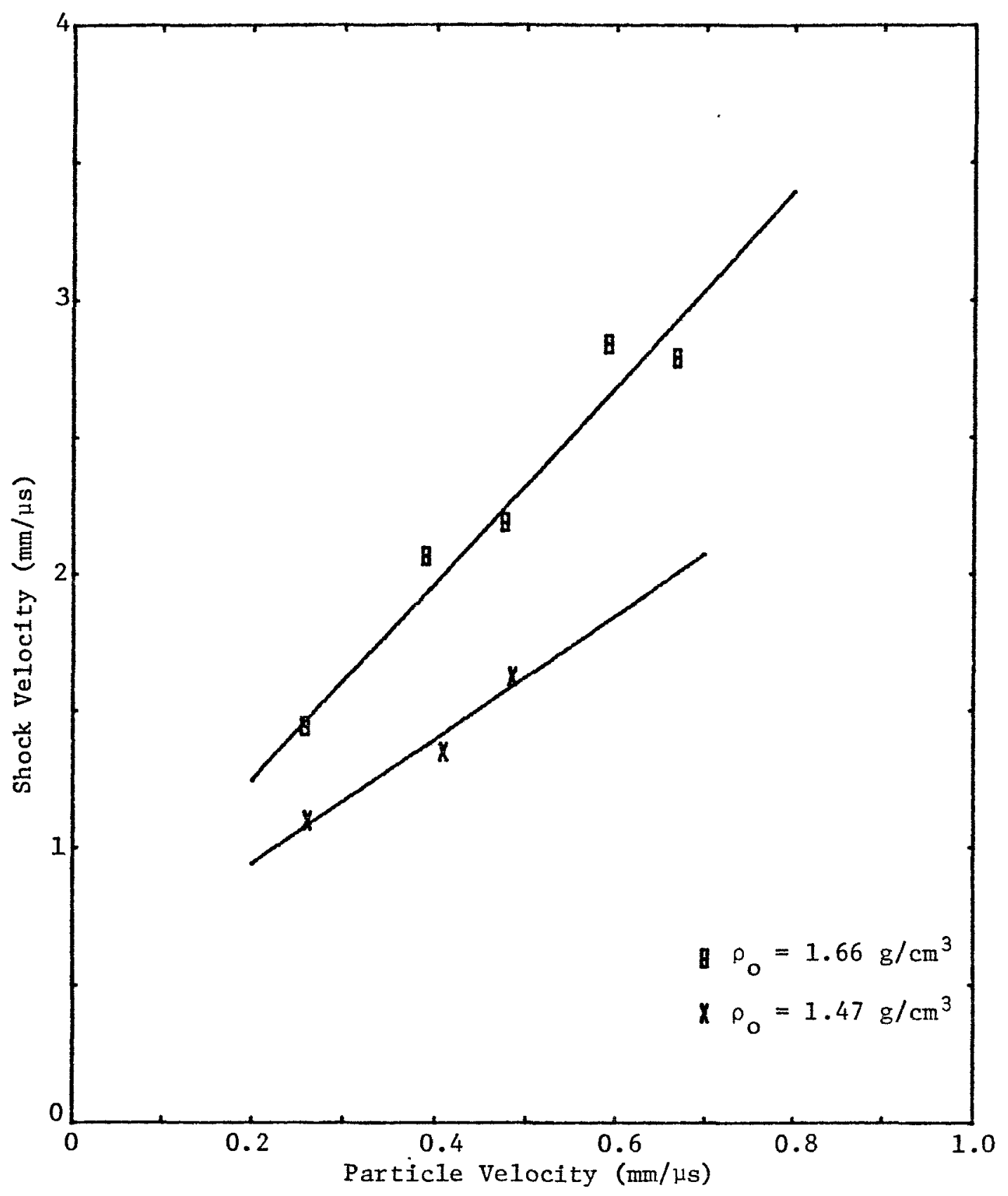

Figure 7. Shock velocity-particle velocity Hugoniot data for porous $C P$ explosive. 


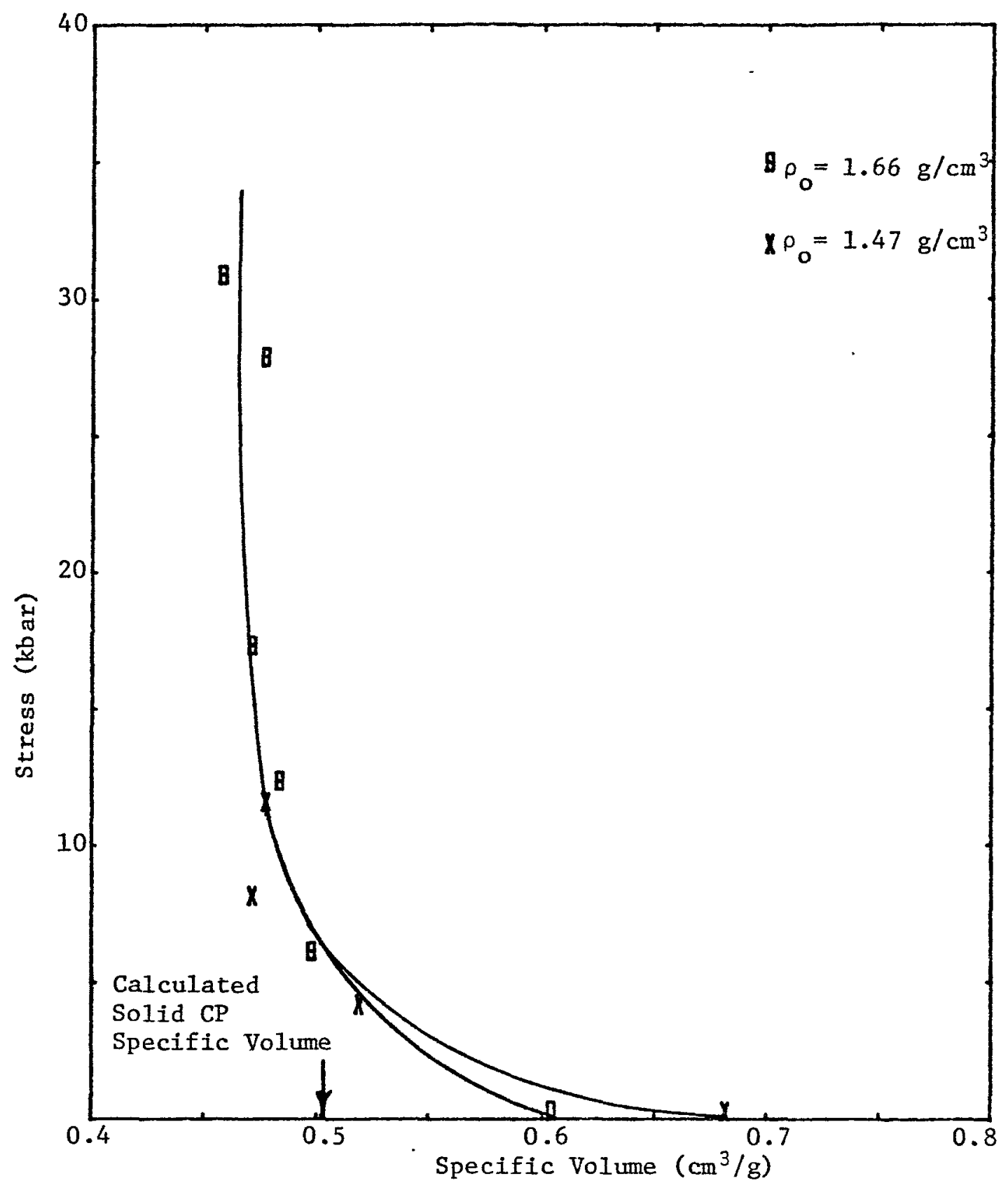

Figure 8. Stress-specific volume Hugoniot data for porous CP explosive. 
Shot 1246

Impact Stress

$4.2 \mathrm{kbar}$

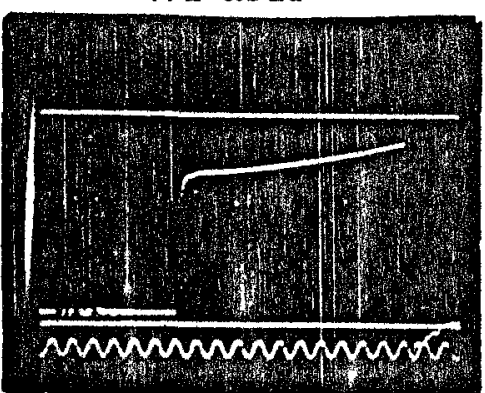

$0.1 \mu \mathrm{s} / \mathrm{T} . \mathrm{M}$.
Shot 1244

Impact Stress

$8.2 \mathrm{kbar}$

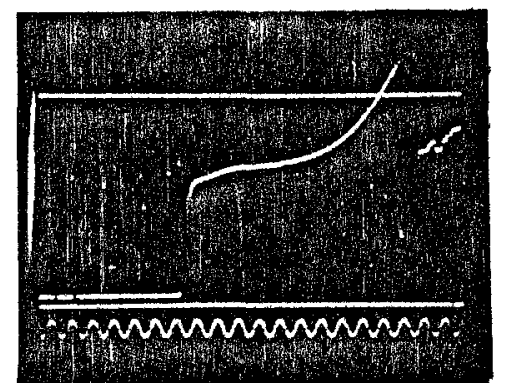

$0 . \dot{1} \mu s / T_{0} M_{0}$
Shot 1243

Impact Stress

$11.6 \mathrm{kbar}$

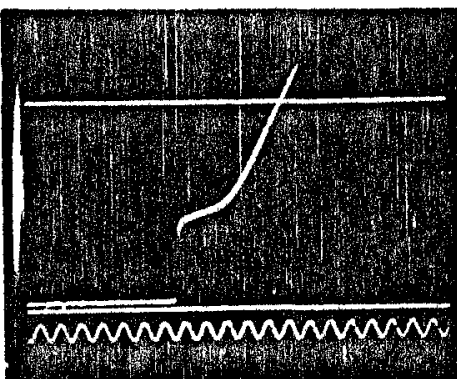

$0.1 \mu s /$ T.M.
Shot 1249

Impact Stress

$18.3 \mathrm{kbar}$

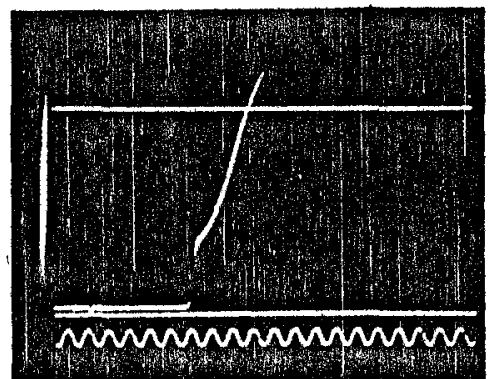

$0.1 \mu \mathrm{s} / \mathrm{T}_{\mathrm{M}} \mathrm{M}_{\mathrm{o}}$
Shot 1250

Impact Stress $19.0 \mathrm{kbar}$

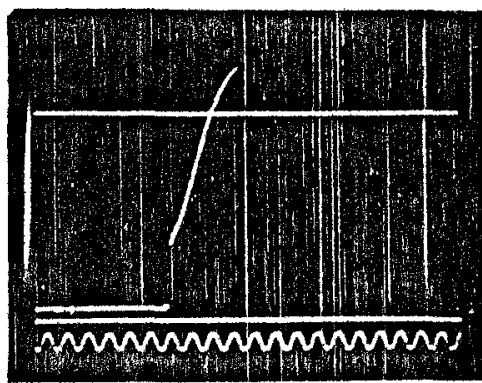

$0.1 \mu \mathrm{s} / \mathrm{T} . \mathrm{M}$.

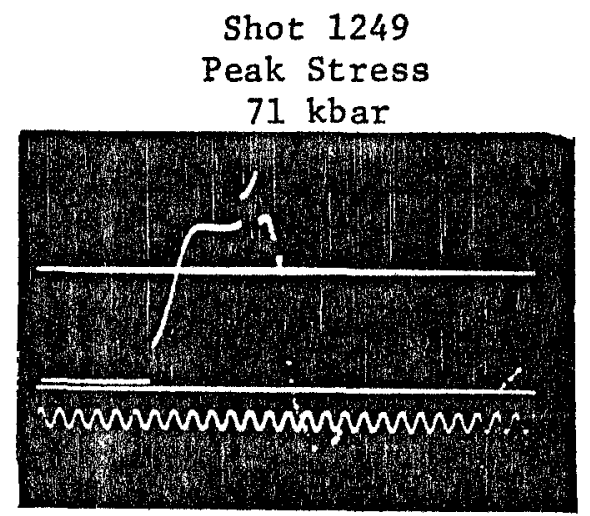

$0.2 \mu \mathrm{s} / \mathrm{T} . \mathrm{M}$.
Shot 1250

Peak Stress

$70 \mathrm{kbar}$

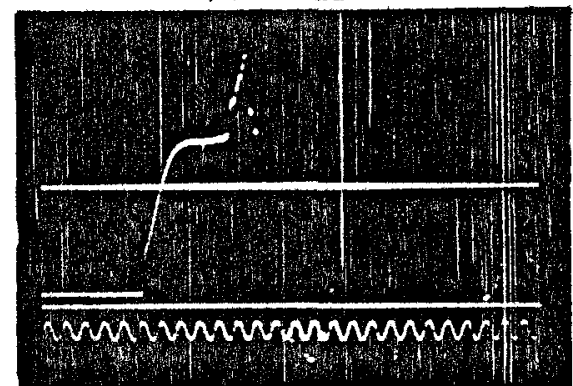

$0.2 \mu \mathrm{s} / \mathrm{T} . \mathrm{M}$,

Figure 9. Sumary of low density $\mathrm{CP}$ impact test data. 
Shot 1253

Impact Stress

6. $2 \mathrm{kbar}$

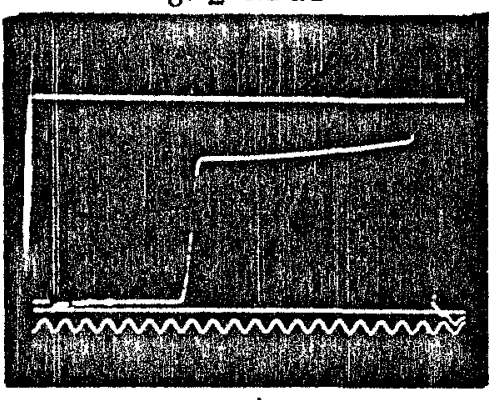

$0.1 \mu \mathrm{s} / \mathrm{T} . \mathrm{M}$.
Shot 1252

Impact Stress

$12.4 \mathrm{kbar}$

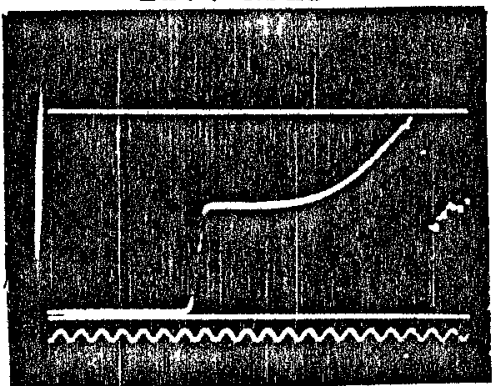

$0.1 \mu \mathrm{s} / \mathrm{T} . \mathrm{M}$.
Shot 1251

Impact Stress

$17.3 \mathrm{kbar}$

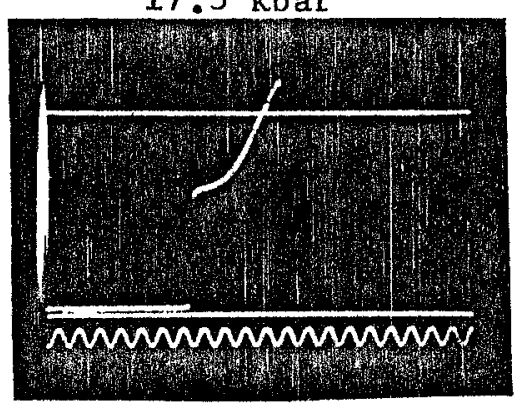

$0.1 \mu \mathrm{s} / \mathrm{T} . \mathrm{M}$.

Figure 10. Summary of high density CP impact test data. 
Shot 1254

Impact Stress

$27.9 \mathrm{kbar}$

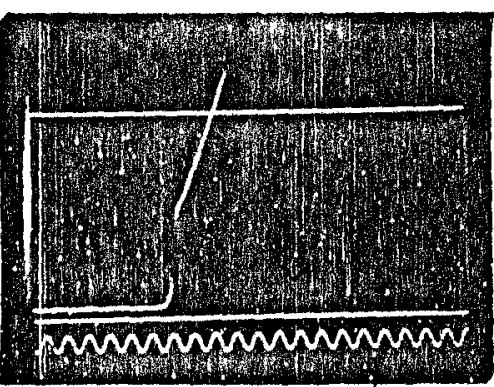

$0.1 \mu \mathrm{s} / \mathrm{T} . \mathrm{M}$.

Shot 1254

Peak Stress 95 kbar

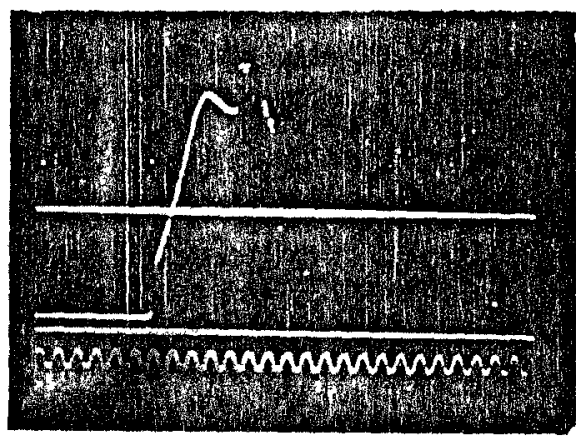

$0.2 \mu \mathrm{s} / \mathrm{T} . \mathrm{M}$.
Shot 1255

Impact Stress

$30.9 \mathrm{kbar}$

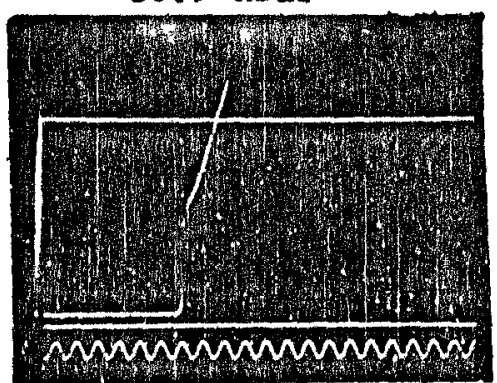

$0.1 \mu \mathrm{s} / \mathrm{T} . \mathrm{M}$.

Shot 1255

Peak Stress

$100 \mathrm{kbar}$

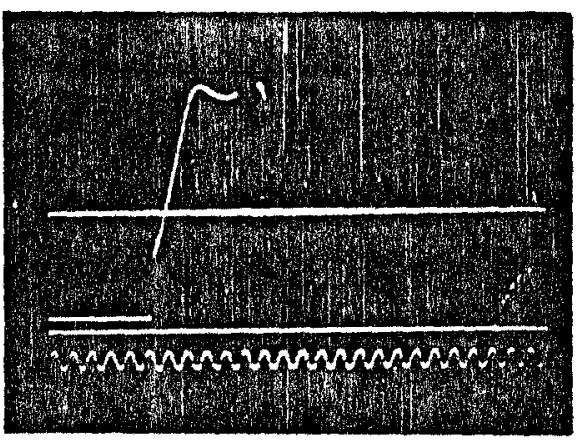

$0.2 \mu_{8} / T . M$.
Shot 1258

Impact Stress

$62.1 \mathrm{kbar}$

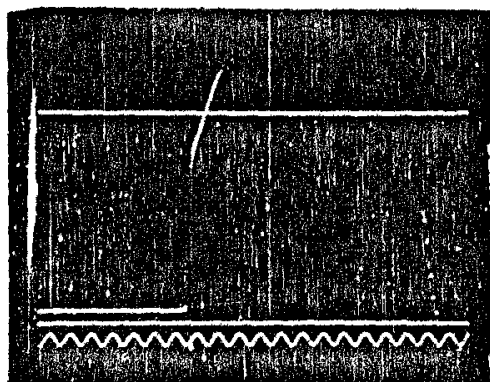

$0.1 \mu \mathrm{s} / \mathrm{T} . \mathrm{M}$.

Shot 1258

Peak Stress

$103 \mathrm{kbar}$

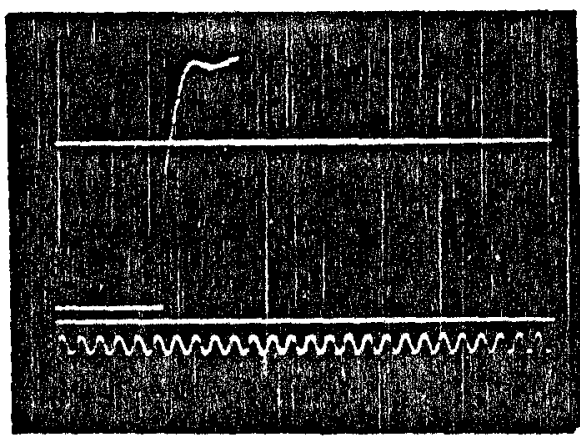

$0.2 \mu s / T_{0} M$.

Figure 11. Summary of high density CP impact test data. 
plateau of approximately $100 \mathrm{kbar}$ was recorded in four experiments conducted on the high density CP with impact stresses ranging from 28 to $62 \mathrm{kbar}$. The experimental data were converted to stress-time at the quartz gauge/buffer intersection, as shown in Figures 12 and 13, with the peak stress values determined from the plateaus listed in Table 3. The experimental data defined the stress-time history at the gauge/buffer plate interface resulting from impact and chemical energy release of the CP sample. The stress-time data shown in Figures 12 and 13 can be used to support reaction rate modeling for CP. 


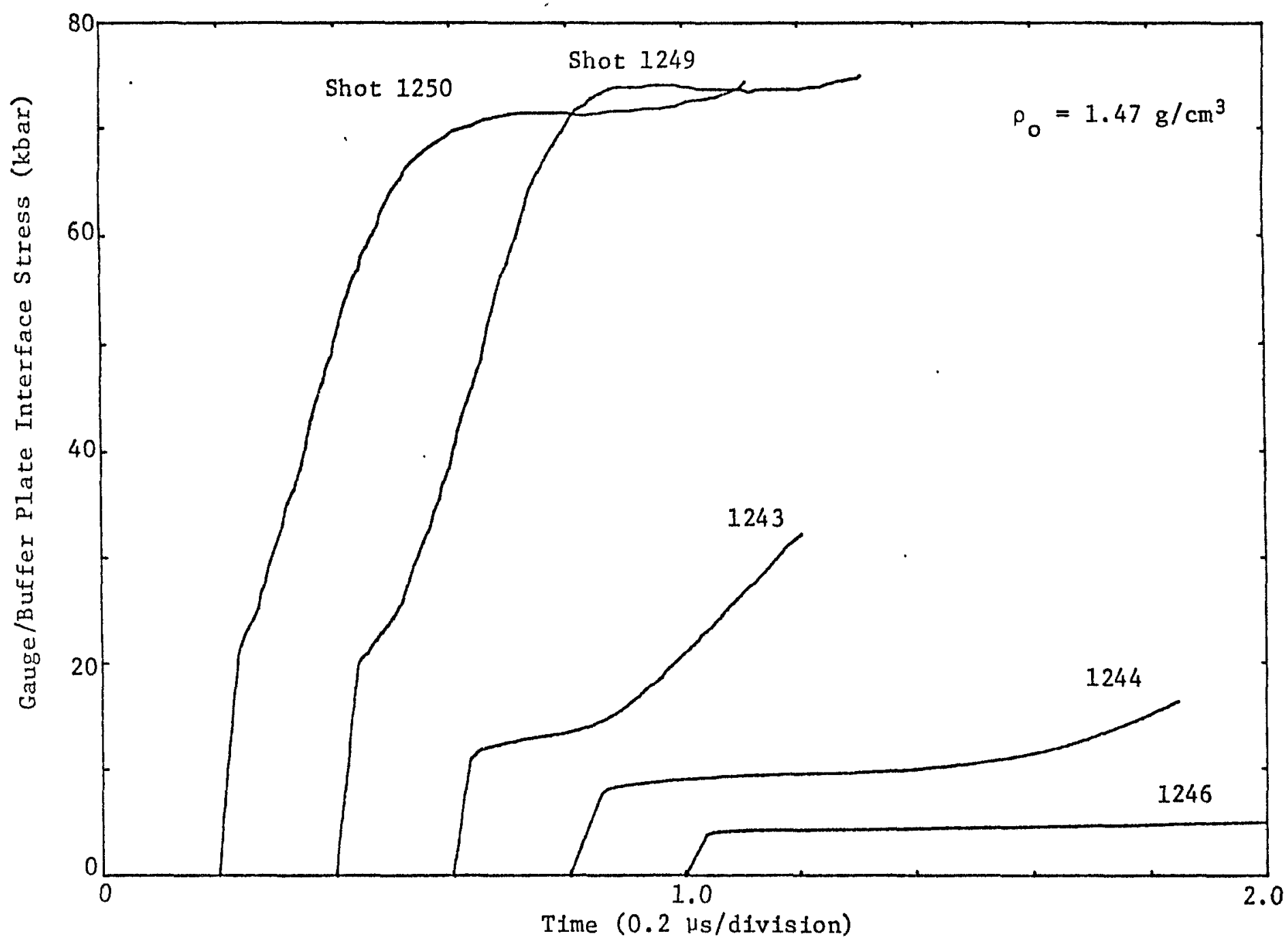

Figure 12. Summary of low density CP stress-time data from impact experiments. 


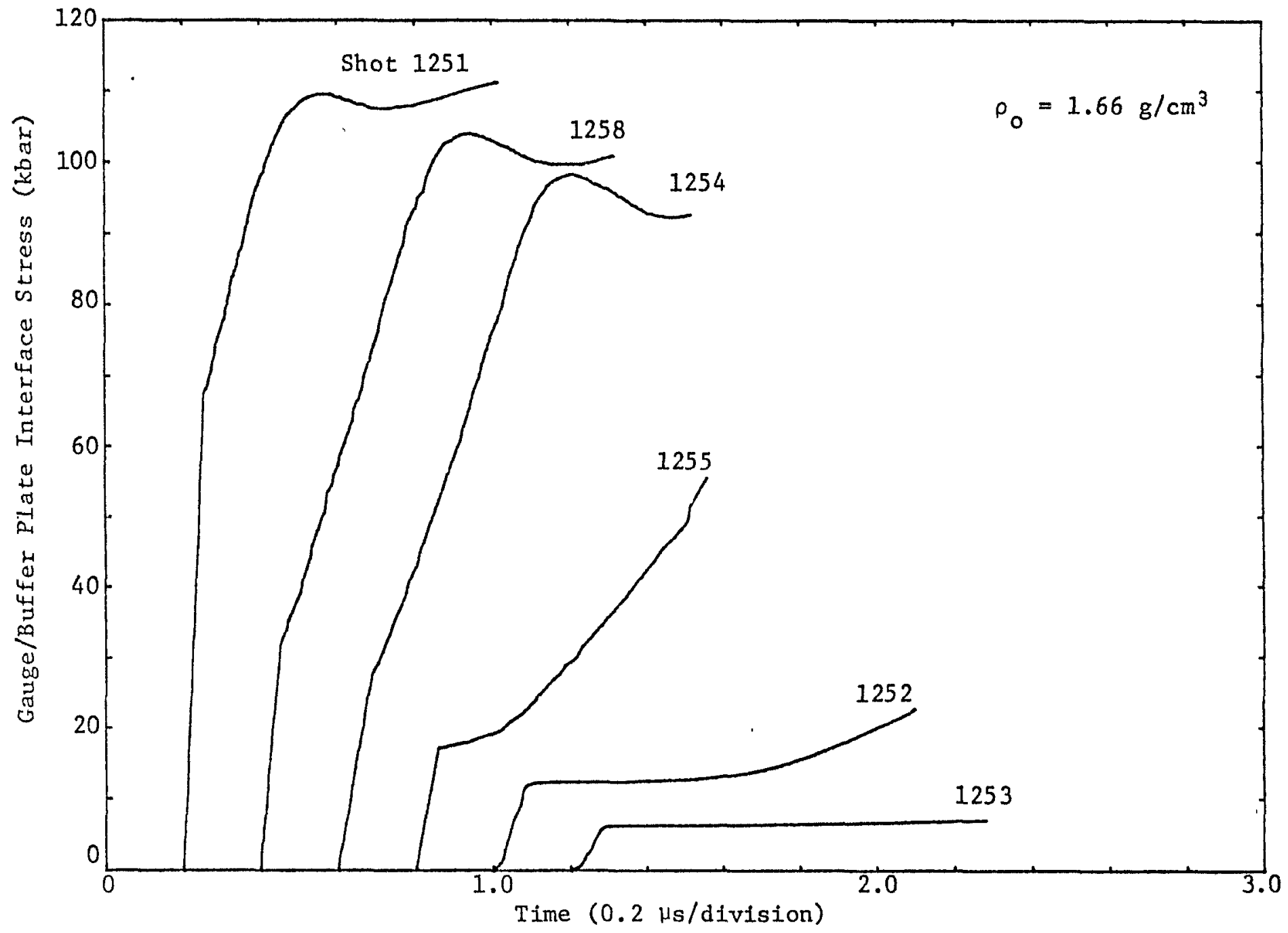

Figure 13. Summary of high density CP stress-time data from impact experiments. 
TABLE 3

SUMMARY OF PEAK STRESSES RECORDED IN CP IMPACT TESTS

\begin{tabular}{|c|c|c|c|c|}
\hline $\begin{array}{l}\text { Shot } \\
\text { Number }\end{array}$ & $\begin{array}{l}\text { Sample } \\
\text { Number }\end{array}$ & $\begin{array}{l}\text { Sample } \\
\text { Density } \\
\left(\mathrm{g} / \mathrm{cm}^{3}\right)\end{array}$ & $\begin{array}{l}\text { Impact } \\
\text { Velocity } \\
(\mathrm{mm} / \mathrm{s})\end{array}$ & $\begin{array}{l}\text { Peak } \\
\text { Stress } \\
\text { (kbar) }\end{array}$ \\
\hline 1249 & $\mathrm{CP} \# 7$ & 1.47 & 0.617 & 71.5 \\
\hline 1250 & $\mathrm{CP} \# 8$ & 1.47 & 0.695 & 69.9 \\
\hline 1254 & CP \#14 & 1.66 & 0.619 & 94.5 \\
\hline 1255 & CP \#15 & 1.66 & 0.698 & 99.6 \\
\hline 1257 & CP 非17 & 1.66 & 0.800 & 99.8 \\
\hline 1258 & CP 非18 & 1.66 & 0.796 & 103.1 \\
\hline
\end{tabular}

* Stress amplitude at quartz gauge/wC buffer interface. 


\section{SECTION V}

\section{CONCLUSIONS AND RECOMMENDATIONS}

Hugoniot data defining the shock loading behavior of the unreacted explosive were obtained up to $30 \mathrm{kbar}$. Experiments at higher impact stress levels did not produce unreacted material data because reaction was initiated essentially at impact. Chemical reaction started at stress levels of 12 and 18 kbar for low and high density CP, respectively. Shock induced chemical reaction was expected at relatively low impact stress levels. However, existance of the high amplitude stress plateau following the rapid stress increase was not anticipated. The stress-time data indicated essentially a constant high amplitude stress state was produced by the explosive at the quartz gauge/buffer plate interface. The experimental results provide a unique set of data that can be used to study deflagration to detonation kinetics. The time resolved data showed the material state produced by impact and the increase of interface pressure due to chemical reactions followed by a high amplitude, essentially constant amplitude pressure state. A number of physical processes included in explosive material modeling can be evaluated using the experimental results.

All of the CP samples were consumed during the impact experiment, either by burning or detonation, based on posttest inspection of the test chamber. This result indicated that the samples tested at low impact stress levels reacted at times later than the recording time of the stress transducer. Major stress increases were observed at times greater ( 1.5 to 3.0$)$ than the onedimensional recording time of the gauge on the low stress level shots. These results indicate that the sample reaction might have progressed to detonation even for the 3 to $4 \mathrm{kbar}$ impacts. Longer recording time experiments should be conducted at low stress levels to investigate this possibility. 


\section{REFERENCES}

1. Fleming, W. and Fronabarger, J. W. (Unidynamics) and Searcy, J. Q. (Sandia Laboratories), "Preparation of 5-Cyanotetrazolatopentaamine-Cobalt(III) Perchlorate, (CP): A New Material for Detonator Applications," Proceedings of ADPA Meeting, Albuquerque, NM, May 15-17, 1979.

2. Graber, E. J. and Morrison, B., "The Secondary Explosive 5-Cyanotetrazolatopentaamine-Coba1t(III) Perchlorate," Proceedings, American Crystallography Association, University of Oklahoma, Norman, OK, March 19-24, 1978.

3. Lee, L. M., Operation of the Air Force Weapons Laboratory Material Response Impact Facility, AFWL-TR-75-287, Air Force Weapons Laboratory, Kirtland AFB, NM, March 1976.

4. Rice, M. H., McQueen, R. G. and Walsh, J. M., in Solid State Physics, "Compression of Solids by Strong Shock Waves," F. Seitz and D. Turnbull, Eds., Academic Press, New York, 1958, Vol. 6, pp. 1-63.

5. Lee, L. M., Shock Compaction Behavior of Porous Titanium Hydride-Potassium Perchlorate, Ktech TR-76-06, Albuquerque, NM, July 1976.

6. Graham, R. A., Neilson, F. W. and Benedick, W. B., "Piezoelectric Current from Shock-Loaded Quartz--A Submicrosecond Stress Gauge," J.Appl. Phys., 36, No. 4, 1965, pp. 1775-1783.

7. Butcher, B. M. and Canon, J. R., "Influence of Work-Hardening on the Dynamic Stress-Strain Curves of 4340 Steel," AIAA Journal, Vol. 2, No. 12, p. 2174 .

8. Barker, L. M. and Hollenbach, R. E., "Shock-Wave Studies of PMMA, Fused Silica, and Sapphire," J. App1. Phys., 41, No. 10, Sept. 1970, p. 4208.

9. Schuler, K. W. and Nunziato, J. W., "The Dynamic Mechanical Behavior of Polymethyl Methacrylate," Rheologica Acta, Vol. 13, 1974, pp. 265-273. 